\title{
Are We on the Right Track? Inserting Democracy System unto Governance Mechanism for Not-For-Profit Organization
}

\author{
Aries Heru Prasetyo ${ }^{1, *}$, Wei $\mathrm{Lo}^{1}$ \& Jersan $\mathrm{Hu}^{1}$ \\ ${ }^{1} \mathrm{Fu}$ Jen Catholic University, Taiwan \\ *Correspondence: 510 Zhongzheng Rd, Xinzhuang District, New Taipei City 24205, Taiwan. \\ E-mail: Justzhongshan@gmail.com
}

Received: October 3, 2017 Accepted: October 26, 2017 Published: November 15, 2017

doi: 10.5296/jcgr.v1i1.11947ＵRL: https://doi.org/10.5296/jcgr.v1i1.11947

\begin{abstract}
Research on good governance mechanism has been done tremendously for more than five decades but not for the not-for-profit sector. The concept is still inclusive and under theorized. Most study focus on adopting concept from commercial sector which is sometimes misleads. This paper tries to find clear evidence by inserting new variables namely democracy. The study begins by looking at the importance of stakeholder and brings in the idea of positioning the society in the organization. Using multiple case analyses in Indonesia, this paper found that types of democracy has a great influenced on how organization sets their governance mechanism. For those who are experiencing an indirect democracy system, democratic governance is the ideal form. Meanwhile for the direct system, compliance model would be the most ideal term. And finally for an active participatory system, the study suggests to use participatory governance model. Among those three, the last model shall be justified as the most ideal form of governance for the sector, thus leaving something for future agenda.
\end{abstract}

Keywords: corporate governance, not-for-profit organization, cooperatives, stakeholder 


\section{Introduction}

As compares to commercial sector, governance mechanism in not-for-profit organization is still inclusive and under theorized (Cornforth, 2004). Some researchers are still trying to dissolve the paradoxical phenomenon (for example Van Puyvelde et al. 2012; Jegers, 2009; Cornforth, 2004) whilst other focus more on existing mature theories (please refers to Crane and Matten, 2016 for ethical theory; Ebrahim et al. 2014 for organizational form theory; Wellens and Jegers, 2014 for accountability theory; Alexander and Weiner, 1998 for the stakeholder theory).

Hereinafter, the use of different theory may influence the direction of analysis and findings. Putting ethical theory as the basic concept, congeniality between current ethical standard and the governance credo must be fully addressed. Therefore if one believed that ethical standard evolve in accordance with society, then the same thing happen to the concepts.

A quite different thought is proposed by organizational form theory. To this concept, governance mechanism is a logical outcome to ensure the achievement of organizational mission and vision. As consequences, the governance is attached to organizational pillars. Changes in the pillars will require amendments to the credo.

For some scholars, organizational-form theory is found to have close relationship with the other two theories (i.e. accountability theory and stakeholder theory). Deriving from theory of the firm, the main reason for an organization to be exists is to serve all stakeholder through direct and indirect approach. Then at the final stage, all these process need to be fairly evaluated by the stakeholder. At that point, governance mechanism should be sees as sets of procedure to ensure that the stakeholder's interest had been fulfilled optimally.

Looking at the previous logic, each organization will passed through from one level to another in terms of good governance evolution. Thus it is necessary to identify the current state of art, where to go and how to do. Only by doing so, not-for-profit can conceive whether they already on the right track or something has to be done.

Analysis of evolution process in organizational governance mechanism had been done for the past two decades and Cornforth (2004) has become one of the forerunners. In the previous article, the author acclaimed six theories which underlying the concepts, namely agency theories, stewardship theory, democratic perspective, stakeholder theory, resource dependency theory and managerial hegemony theory. Among the stated theories, categorization had been done only by focusing on variety of interest between parties. Furthermore, the flow of thought is used to justify the board role in formulating the final model.

Concerns like these have leads to the new way of thinking. But focusing only to the point of interest would mislead. One need to consider types of democracy system among society since the higher the tension of democracy, variety of interest may exist. In this paper, we try to extend the idea by inserting democracy as key driver for categorization. Using multiple case study approaches, the paper addresses two related problems. First, is it important to consider types of democracy system as trigger to governance mechanism in this sector? Series of in 
depth interview among management team and representative of society, field observations and document analysis had been done to maintain the objectivity of findings. One important premise of the paper is that a number of previously stated theories are useful to be extended to the context of not-for-profit organization.

However, this raises a second related problem as; having inserting the role of democracy, what would be the most ideal model for governance mechanism for this sector. By giving more attention to the levels of democracy among society, the study may objectively justify the existence of interest's indifference which leads to the Board role, thus portraying the final model.

The rest of the paper will be as follows: on section two the paper will perform a qualitative meta-analysis to gain new insight relating to (1) how types of democracy may trigger diverse interests, (2) how the board deal with this issues especially when they come from particular groups of society and (3) how they provide a balance mechanism among diverse interests. Section three declares method used in the study, section four explains finding, discussion and implications while section five poses the conclusion of the study.

\section{Literature review}

A variety of theories have been proposed to disentangle the process of good governance within organization, including for social sector. Some of them are succeeded in clearly identify the role of board in dealing with such circumstances. In this section, several theories and associated model is carefully analyzed to identify which theory works best for the nonprofit sector. However, the study begins with analyzing the role of democracy in directing governance mechanism among organization.

\subsection{Exploring Organizational Democracy}

To pose the importance of considering organizational democracy in terms of good governance, the study begins with the idea of economic democracy. Concept that was first introduced by Dahl (1985) emphasize on three vital elements: democracy, liberty and equality. From this stand point, democracy is seen as means to achieve the balance condition between the rights of liberty and demand for equality. It's all start with the appreciation of human rights (the right to life, free of discrimination, rights to the pursuit of happiness and rights to liberty and freedom). Having understood that every member of the society will pursue their rights then, it is important for an organization to set the rule through a mechanism namely democracy. In practical terms, democracy is revealed by freedom to raise their voice and opinion (Joo, 2003). Once the freedom is granted then governance mechanism must be designed to deal with varieties of interests.

Without prior justification in organizational democracy in terms of politic, this study tries to accept the idea of liberty and freedom in a positive manner. Along with Solomon (2017), Moriarty (2016) and Sauerwald et al. (2016) we pose premise that the existence of liberty and freedom to share opinions are very important to enforce good governance among 
not-for-profits. Public opinion must be acknowledged as insights for future improvement. However, organizational democracy may consist of: (1) direct method in which the owner grants access to raise their voice to the management. Due to its vocals, this method is always seen as trigger for any dynamic and radical changes in organization. (2) The second method is an indirect democracy in which every voice will be presented through group of owner's or member representative. To some scholar, the method may create stability in organizational performance but it also takes another bureaucracy mechanism. (3) The third method is a participatory democracy in which owner or member has access to control and actively manage the organization. Though it seems ideal but separation among the two roles should be done objectively. Otherwise they will create another challenge to governance context. Recalling the levels of democracy, below are some possible models for good governance at the context of social sector.

\subsection{A Democratic-Governance Model}

One prominent leading scholar in this field is Thomas M. Frank. Using social-community as a context, a democratic-governance is seen as the unprecedented outcome from the development of public knowledge. Deploying the analogy of knowledge as a living creature, he gave an example of how things that previously mentioned as a want now can be understood as a need when collective people acclaimed that. The same phase also happened in terms of rights. Today, more people had aware their position as the strategic partner of an organization. Customer has now been identified as company's real decision maker. And as their voice begins to be fully appreciated by the business sector, the stakeholders are now able to maintain their vital role. Moreover, this is the basic of democratic-governance model (Frank, 1992).

Giving power to the community to raise their voice does not mean without problems. New challenges had occurred such as marketization of not-for-profit (Eikenberry, 2009), profit-seeker philanthropist (Guo, 2007) and politics-driven matters (Clemens, 2006). To deal with these challenges, membership-platform had been proposed. With this predetermined section, it is plausible for the Board to maintain the model on its highest productivity. Multiple screening process can be applied to find the most appropriate and eligible idea to develop the organization. One possible way is by acknowledging the role of indirect democracy. Several underlying theories for this model are: democratic perspective theory, resource dependency theory and managerial hegemony theory.

\subsection{A Compliance Model}

At the context of direct democracy, owners or members has the right to pose their voice directly to the organization. Media such as initiative and referendum mostly being used to raise any counter idea to the management (Lupia and Matsusaka, 2004). Like in political fields, direct democracy is characterized by wide gap between owner and management perspective. For most cases, owners are more concern to long term performance while forgoing the short-run process. It is in contrast to management perspective. As for management, short term performance is more important since it has direct impact to their monetary benefits such as annual bonus, career promotion or even sustainability of the 
organization.

In order to deal with the current gap, governance mechanism must be able to protect owner's interests. That is why a compliance model is believed to be the most effective mechanism. Referring the works of Luviene et al. (2010), in order to develop sustainable economic-democracy in nonprofit organization (for example cooperatives), governance mechanism must be set to ensure that opinions which come from initiative or referendum may have their own portion in the decision making process. At this point, a productive communication channel must be built to provide an equal access to all members to raise their voices. Having the mechanism we may have a warranty that the efforts to minimize the agency-gap will work well. One underlying theory for this model is an agency cost theory.

\subsection{Partnership Model}

Another possible model came from the stewardship theory. Departing from Donaldson and Davis (1991) differences between stewardship concept and the agency can be found on its argument towards shareholder's interest. To agency theory, the only way to protect the owner's or member's interest is by separation of incumbency of roles of the board. Meanwhile stewardship theory mention that the protection must be done through shared incumbency of the roles. This is why from democracy perspective stewardship theory can be implemented through participatory democracy.

Drawing back from Dahl (1985), Green (1985) and Barber (1984) which then is extended by Pestoff and Hulgard (2015), every party in nonprofit organization must fully aware that each of them are actually bears the responsibility of so called stewardship. A member must realize that they do not only belong to the organization but also as a vital component in the society. Therefore their co-existence in the organization must address the interest of their specific group of society. Furthermore, this would lead to a paradigm in which an individual member must be able to raise two sides of interests - the organization and society. Thus, an active participation in the organization must be seen as an expression of their responsibility.

On the other hand, management is also having the same thoughts. They share the willingness to work together in order to accomplish both interests. Again, the intersection of these two thoughts would be a partnership model to ensure that each party's interest will be protected in a fair way.

The main features of the three models are summarized in Table 1. Each model is described by considering the type of democracy, characteristic of interest among party, board role and some support from existing theory. 
Table 1. Model Summary

\begin{tabular}{|c|c|c|c|c|}
\hline $\begin{array}{c}\text { Type of } \\
\text { democracy }\end{array}$ & Governance model & Interest & Board role & $\begin{array}{l}\text { Support from } \\
\text { existing theory }\end{array}$ \\
\hline Indirect & Democratic-governance & $\begin{array}{l}\text { Variety of interest } \\
\text { is found within } \\
\text { society, member, } \\
\text { owner and } \\
\text { management of the } \\
\text { organization }\end{array}$ & $\begin{array}{l}\text { More to politics } \\
\text { since they have to } \\
\text { be a good } \\
\text { moderator to find } \\
\text { win-win solution } \\
\text { which addresses all } \\
\text { interest together }\end{array}$ & $\begin{array}{c}\text { Democratic } \\
\text { perspective theory, } \\
\text { resource } \\
\text { dependency theory } \\
\text { and managerial } \\
\text { hegemony theory }\end{array}$ \\
\hline Direct & Compliance model & $\begin{array}{l}\text { With the absent of } \\
\text { society, variety of } \\
\text { interest is found } \\
\text { between } \\
\text { organizational } \\
\text { member and their } \\
\text { management team }\end{array}$ & $\begin{array}{l}\text { More to conformity } \\
\text { in which the board } \\
\text { must ensure the } \\
\text { primary point of } \\
\text { owner's interest }\end{array}$ & Agency theory \\
\hline $\begin{array}{c}\text { Active } \\
\text { participatory }\end{array}$ & Partnership model & $\begin{array}{l}\text { Through a } \\
\text { productive } \\
\text { communication } \\
\text { process, share } \\
\text { interest among } \\
\text { society, member, } \\
\text { owner and } \\
\text { management can } \\
\text { be achieved }\end{array}$ & $\begin{array}{l}\text { More to value } \\
\text { enhancer in which } \\
\text { the board must be } \\
\text { able to preserve the } \\
\text { positive condition } \\
\text { as mean of } \\
\text { democratization }\end{array}$ & $\begin{array}{l}\text { Stewardship } \\
\text { theory }\end{array}$ \\
\hline
\end{tabular}

Source: Authors compilation

\section{Method}

A multiple case analysis is used for clarifications of each model. Two groups of hospital, two private universities, and two rural banking cooperatives - all in Indonesia are chosen to provide some insightful evidences. A formal invitation followed by visitation is done to gain access to the unit of analysis during March to April 2017. From six candidates, three had decided not to receive the invitation, leaving one group of hospital, one private university and one banking cooperative under Credit Union. Series of in depth interviews among board member of each unit are done during May to July 2017 using formal questionnaires and proceeds by formal information consent. This step is producing preliminary finding to justify governance model that had been used by unit of analysis. A cross-case analysis is done to grasp the general model followed by three months of field observation. In this stage, document analysis is done to carefully examine whether the specified model is truly undergone. The study use coding system to find evidence of board role from written document such as meeting agenda, meeting notes, letters of board policy and decision and other related facts.

After carefully analysis all available document, formal discussion with each unit of analysis was done to clarify the findings. New insights and opinions are then being accommodates to our final model, followed by several points for future consideration. 


\section{MInstitute"}

\section{Finding and Discussion}

\subsection{Governance Mechanism at a Group of Maternity Hospital}

The hospital was founded in 1983 and now has been operated in more than 7 provinces with 27 branches, serving more than 8,000 patients annually. Supported by 321 medical staffs and 612 nurses, the hospital has become one of community referral medical services. In early 2000, an organizational restructuring had been done in response to public demands for professionalism. As a result, a holding company was established as parent for all subsidiaries (called branches). Moreover, a categorization of five regions was also done to enhance managerial coordination among branches.

In 2010, begin with the holding company as parent, the hospital started to adopt the concept of corporate governance. An independent commissioner was then elected to fulfill the requirement of good governance. A separation between shareholder - as represented by board of commissioner and the board of director as management function was done to ensure the objectivity of the mechanism. Moreover, a new director who specialized in corporate governance had been elected. He works together with compliance committee which then merged with internal audit team to provide guidance, monitoring and improvement strategy for governance mechanism.

On early 2012, the hospital decided to fully adopt the concept of good corporate governance which leads by the National Commission on Corporate Governance Republic of Indonesia. Revisions of mission statement as well as the creation of good governance credo and ethical conduct were done by direct supervisions from the national team. During periods of 2012 to 2015, the rise of risk management concept had brought significant impact to governance mechanism. As part of national health industry, the hospital shares the obedience to the new policy which requires the full implementations of risk-based governance. As a result, Director of governance has now become the Director of Risk and Compliance. Under this position, one unit has been added namely risk management. In general, the governance mechanism can be seen on Figure 1.

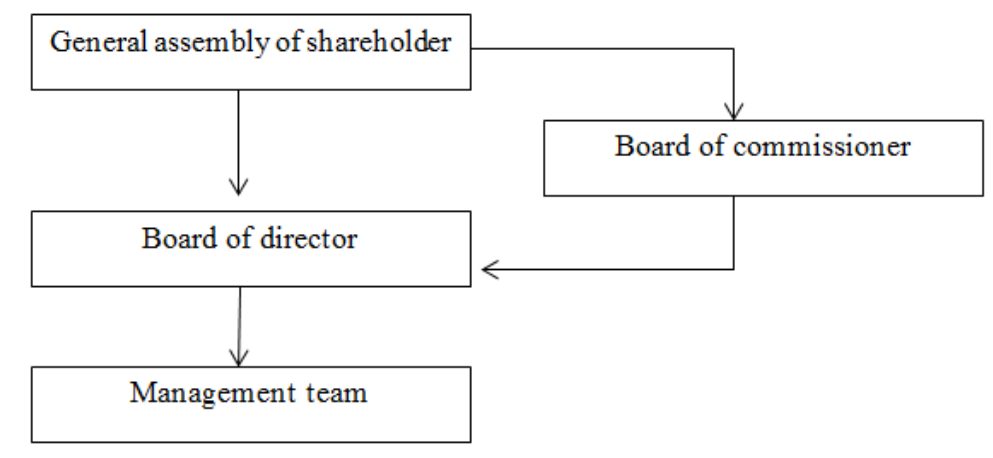

Figure 1. Governance Mechanism for Hospital

Source: Authors conceptualization 
As for governance matter, the hospital uses a direct democracy system. Each branch has the rights to raise their voice to Board of Director. On semi-annually basis, the Board representative held an open forum in each regional office which usually attended by branch staffs. In this open discussion, every concern and opinion is freely raises to become national agenda. Although the system seems to works well, but our analysis found ineffectiveness points. From 2013 to 2016, using document analysis, on average there was only less than $14 \%$ of the total concern which has been discussed on national agenda found its best solution. This has an impact on the credibility of risk and compliance department as well as the governance mechanism itself.

From the in depth interview, several problems had been successfully portrayed. First is the absence of public domain in organizational governance. The use of direct democracy system has leads the hospital to partially excluded society's interest in the system while on the other hands they are serving the society. Thus, it takes miracle for the organization to achieve the optimum satisfaction from the community. Our secondary document (using newspapers and magazines) found two risk and governance related cases which happened in 2014 and 2015. This proves that the absence of public domains is a vital thing.

Second problem is relating to communication flow in terms of governance mechanism. Separation between knowledge management and governance system has found to be a critical point. We hardly found evidence for lesson learned from each disobedient which leads to image construction. Documentation is only for recording matters and yet nothing to do with future decision making.

However, this raises the third problems. New member of the organization doesn't know the true history of how important to work under governance credo and ethical conduct. Most employees only see their job as means to earn living which is absurd in terms of medical services. And uniquely, they even have not yet realized that they are part of society who will be served by the hospital. Finally, more strategic approach is needed to overcome the problem.

\subsection{Governance Mechanism of a Private University}

The university was founded in 1967 by the Catholic Priests and had been serving the community in Central city of the nation's capital for more than 50 years. To date they have been brought more than 20,000 alumni who serve as politician, actor, academicians and entrepreneur. Supported by 182 academicians and 233 staffs, the university has offers not only formal higher education but also business consultancy and training for the companies. The university had adopted good governance mechanism starting from early 90's. Begin with adjusting the mission, vision and strategic statement, the university tried to implement the concept properly.

During the early stage, they had extended the definition of stakeholder and positioning the society as their point of interest. In gradual, from 1997 to 2007 they invited public figure to fill in the position as board of trusty while withdrawing all internal parties from the board. This is in response of their commitment to put public interest at the highest point. Using 
indirect democracy system, through an open publication in mass media, communities are invited to join the selection to become members of the board of trusty. Strong collaboration among parties tends to support the governance-partnership model. The flows of governance mechanism for this unit can be seen on Figure 2.

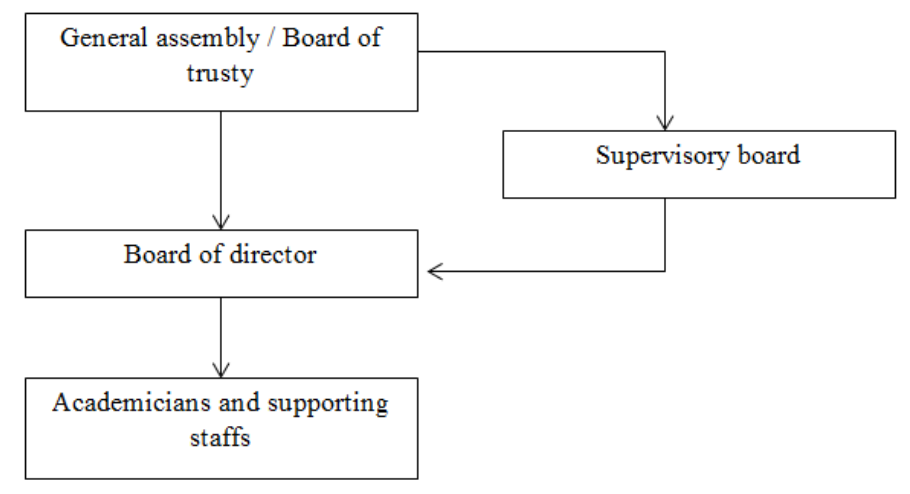

Figure 2. The Governance Mechanism for Private University

Source: Authors conceptualization

After gone through series of selection process, the board held periodical meeting on semi-annually basis. They raise all issues as input to managerial team. Our documentation analysis had found that up to $78 \%$ of the total issues are being solved by the management. This is supported by satisfaction index from the society which had been surveyed. For the past five years, the index shows slightly positive trends. Unfortunately there is no single explanation about this issue.

As compares to the previous case, the university has started to show the lesson and learned from past cases. A good recording mechanism has been performed for the past four years. But again, separation between knowledge management system and compliance process had found. Traditional treatment for compliance document is still happen. This is why in the interview session, in majority, our informant mentioned that it is time consuming for them to retrieve all written document just to learn what was going on in the past as crucial point for future decision or policy.

Another concern is on how to accommodate any public interest in timely manners. Our analysis goes to the inconsistencies between response to the needs of the society and numbers of students and clients that had been served by the organization. A wider gap from time to time had raise question regarding the composition of the trusty board.

Diversity of social and expertise background among member has been found as one important issue. As note to that, several boards have also found to perform duality - in which they serve two boards in different university at the same time. This might have a direct-negative influence in managing the organization. For future improvement, our study signaled the important of evaluating the criteria in selecting the board. Comprehensive due-diligence is needed to ensure one's capability and commitment to become the board of trusty. And at the top of considerations, experience in educational matters is important. 


\subsection{Governance in Banking Cooperatives}

Our study has the opportunity to learn the governance mechanism on banking cooperatives under Credit Union - an international credit cooperative alliance. Serving more than 300,000 members for at least 30 years, the banking cooperative has become one of important organization for the society especially those who live in rural areas.

Starting from early 2000, the international alliances had fully adopted corporate governance. As opposed to the first two cases, the Credit Union has been promoting participatory democracy as a mean to develop economic-democracy among society. The system is done by inviting society to take part as their strategic partner by offering special position in general assembly. Moreover, every member has been given an invitation to actively join the monitoring scheme. Every insights and opinion can be addressed timely to the management team. This creates an opportunity for the management to serve the society in a better way. The flow of governance mechanism can be seen on Figure 3.

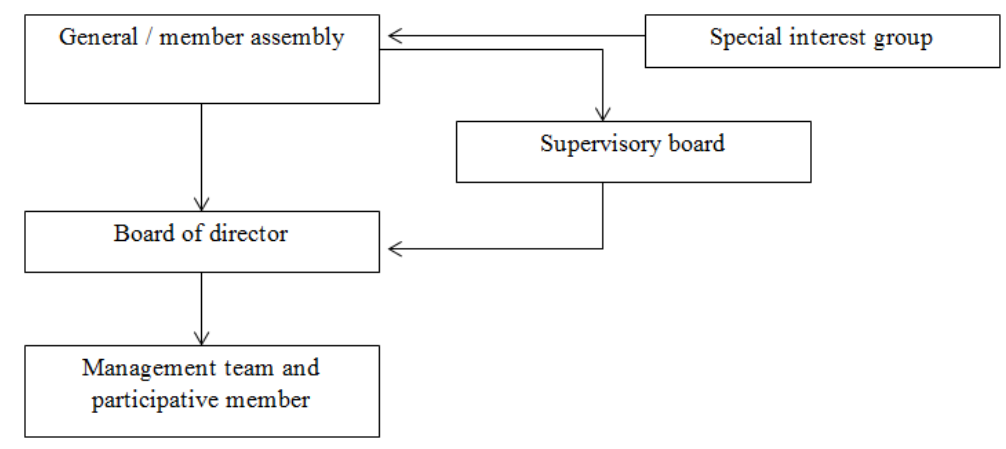

Figure 3. The Governance Mechanism in Banking Cooperatives

Source: Authors conceptualization

One of the greatest achievements was in 2015 of the organization had been awarded for the best implementation in good corporate governance. This must be the biggest motivation to search for improvement in the coming years.

Although the system can works well, our field observation and documentation analysis signaled some potential issues. First is relating to the inactive of knowledge management system in the organization. Being operated under participatory democracy system, the organization faces risks due to conflict of interest. A shared incumbencies between society, member and management require self-reliance to fully appreciate others interest. Now, in order to provide a fair-game, every party needs to learn from the past. Therefore the absence of knowledge management makes it difficult for those who want to adopt this thought.

The reality creates second issues. As what we learned from the university case, duality in the position of special interest group had also been found. From documentation analysis, our study found several names that serve other banking cooperatives within the same periods. This might leads to another problem in terms of governance. Moreover, the duality problem 
in this type of organization is very complex and unsolved. Members of banking cooperatives hold more than two memberships at the same time. Similar things happened at the management level. This critical condition needs to be solved shortly otherwise it will damage the image of the governance system itself.

\section{Discussion}

\subsection{Fitness between Types of Democracy and Governance Model}

As opposed to Cornforth (2004) among four unit of analysis, the study identified clear evidence that in adopting the model, nonprofit organization considered types of democracy embraced by organization. Using hospital and university as examples, we pose the new insight that democracy has vital implications on the creation of diverse interest among party. In the context of diverse societies, the demand to give more attention to each interest will be greater especially when each individual is given enough opportunity to convey their thoughts. This is evidenced by banking cooperatives. The application of participatory democracy system has leads the organization to face complexity in corporate governance. This study gives strong support to Putnam et al. (2016), Berry and Wilcox (2015), Coule (2015) and Rothstein (2001).

Not-for-profit organizations which follow indirect democracy system tend to adopts democratic-governance model. In this model, the board plays an important role as politician. They share the responsibility as the matchmaker among available interest. On contrary, organization which adopts the direct democracy found its fitness with compliance model. In contrast to the previous example, within the direct forms, organization begins to address the role of society by setting up special position with the absence of all internal parties. For one reason, this is good to maintain the objectivity of the thoughts.

The most complexities phenomenon is found at participatory democratic system. More participants who are coming from different background and expertise have leads the governance mechanism to absurdity. They are not only lost its power but also turn into new problem. Our study witness that failures in solving this issue may create a silent-chronical problem.

\subsection{Portrayed Challenges}

Though impressed without any problems, the application of good governance in nonprofit organization needs further analysis. Two potential issues had been identified in this study. First is relating to the relationship between knowledge management and governance concept. This issue had been raised by Carpenter and Westphal (2010) but unfortunately they had not received any support. Our study found that the idea is genuine with highest probability of success.

Let us now retrieve from Gold and Malhotra (2001) seminal article on knowledge management. KM system is proposed as comprehensive mechanism to ensure that every data can be stored and easily being converted into valuable information (or also called knowledge). 


\section{Mll Macrothink}

Journal of Corporate Governance Research ISSN 1948-4658 2017, Vol. 1, No. 1

Further development of KM is aiming to provide timely support for strategic levels, not only upon technical matters, including as productive communication channel to pursue an effective democracy (Buuren, 2009; Foss, 2007; Grandon, 2001). At this point KM infrastructure can be useful tools to support the governance mechanism. Furthermore, automation and digitalization of data can be the best learning media to spread out the idea of governance. With this system, good governance can be blend with daily activities.

The second challenge is on the levels of mindset. Although the concept of governance in NPO is still under theorized but our study identified the need to redefine who is stakeholder and how organization must be accountable to them. The four cases show that providing the ideal position to the stakeholder is still beyond expectation. As a social movement, the organization must be actively accommodates stakeholder's interest in their strategic decision, thus participatory democracy as well as partnership governance model is a vital element for sustainability.

In this study, we found that process of mindset changes is a never ending effort. We may see that length of time in pursuing good governance has not guarantee the quality of the outcome. For this purposes, our study posited that the society needs to have higher maturity in seeing corporate governance as an obligation.

Another crucial matter is due to duality phenomenon. An advanced strategy is needed to make society shares awareness that the problem of governance is actually the real issues of the communities. Spirits of accountable is not only beard by the organization but more to society as an individual. Any failure in minimizing this problem may leads to inefficiency and at the same time it creates boomerang to the concept of governance.

\section{Implications}

This study shares important contribution to corporate governance concepts especially for the nonprofit sector. Known as a social movement, not-for-profit must start with understanding who is their respective societies in whom they may call 'stakeholder'. Once the process of identification finished, they need to provide space for stakeholder to raise their interest. This is where the role of democracy must be strengthened. However, governance type should be chosen by considering the fitness with the type of current-democracy. A participatory model is believed to be the most ideal governance model for the sector.

For the practical terms, having considered the maturity levels of society in democracy, our study suggested that each organization beard the responsibility to develop their knowledge to be more accountable to their communities. All elements within governance mechanism structure must fully aware that since they are part of society, then they need to maintain the objectivity in decision making process. 


\section{Conclusion}

The paper had briefly discusses about the importance of considering types of democracy in designing the governance mechanism for not-for-profit organization. Using three unit of analysis from different industry (health care, education and banking cooperative) our study provide evidences that it is important for social organization to provide access to the community to join in the governance process. One possible ways is by having society's representative as organizational counter party. Referring to the university case in this paper, we can see that through better selection procedure, representatives have the ability to raise the voice of the society. This is beneficial to internal organization since they may clearly define the needs of the communities. By doing so, the most ideal model for this sector would be participatory governance.

The second concern goes to the important use of knowledge management system. We had witnesses that corporate governance in social oriented organization as well as in other type of organization is a never ending learning process. Therefore, great support from the KM system is needed to record any lesson learned from past experience to be converted into valuable consideration for future decision making.

We truly realize that our study failed to find evidence on other industrial cluster which social units may exists. Future works must be able to explore new finding using different types of industry. Another signal that has been identified during our observation is the role of culture for learning and growth. Governance mechanism in the education sector tends to works well than the other sector. And this is due to their learning environment. Conducive learning - as the outcome from knowledge management is needed to carry on the idea of good governance.

\section{References}

Alexander, J. A., \& Weiner, B. J. (1998). The adoption of the corporate governance model by nonprofit organizations. Nonprofit Management and Leadership, 8(3), 223-242. https://doi.org/10.1002/nml.8302

Barber, B. R. (1984). Strong democracy: Participatory politics for a new age. Berkeley: University of California Press.

Berry, J. M., \& Wilcox, C. (2015). The interest group society $\left(5^{\text {th }}\right.$ ed.). Routledge: Taylor \& Francis Group, New York.

Buuren, A. (2009). Knowledge for governance, governance of knowledge: Inclusive knowledge management in collaborative governance process. International Public Management Journal, 12(2), 208-235. https://doi.org/10.1080/10967490902868523

Carpenter, M. A., \& Westphal, J. D. (2010). Corporate governance and knowledge management: How board independence may increase CEO paranoia and lead to increased top management team homophily. International Journal of Strategic Management Change, 2(4), 143-155 https://doi.org/10.1504/IJSCM.2010.03585 
Clemens, E. (2006). The constitution of citizens: Political theories of nonprofit organizations. The nonprofit sector: A research handbook. Yale University Press.

Cornforth, C. (2004). The governance of cooperatives and mutual associations: A paradox perspective. Annals of Public and Cooperative Economics, 75(11), 11-32.

Coule, T. M. (2015). Nonprofit governance and accountability: Broadening the theoretical perspective. Nonprofit and Voluntary Sector Quarterly, 44(1), 75-97.

Crane, A \& Matten, D. (2016). Business ethics. Managing corporate citizenship and sustainability in age of globalization. Oxford University Press.

Dahl, R. (1985). A preface to economic democracy. Berkeley: University of California Press.

Donaldson, L., \& Davis, J. H. (1991). Stewardship theory or agency theory: CEO governance and shareholder returns. Australian Journal of Management, 16(1), 49-68.

Ebrahim, A., Battilana, J., \& Mair, J. (2014). The governance of social enterprises: Mission drift and accountability challenges in hybrid organizations. Research in Organizational Behavior, 34, 81-100. https://doi.org/10.1016/j.riob.2014.09.001.

Eikenberry, A. M. (2009). Refusing the market: A democratic discourse for voluntary and nonprofit organizations. Nonprofit and Voluntary Sector Quarterly, 38(4), 582-596. https://doi.org/10.1177/0899764009333686

Foss, N.J. (2007). The emerging knowledge governance approach: Challenges and characteristics. Organization, 14(1), 29-52. https://doi.org/10.1177/1350508407071859

Frank, T. M. (1992). the emerging right to democratic governance. The American Journal of International Law, 86(1), 46-91.

Gold, A. H., Malhotra, A., \& Segars, A. H. (2001). Knowledge management: An organizational capabilities perspective. Journal of Management Information Systems, 18(1), 185-214. https://doi.org/10.1080/07421222.2001.11045669

Grandon, A. (2001) Neither hierarchy nor identity: Knowledge-governance mechanisms and the theory of the firm. Journal of Management and Governance, 5(4), 381-399.

Green, P. (1985) Retrieving democracy: In search of civic equality. Totowa: N.J: Bowman and Allanheld.

Guo, C. (2007). When government becomes the principal philanthropist: The effects of public funding on patterns of nonprofit governance. Public Administration Review, 67(3), 458-473. https://doi.org/10.1111/j.1540-6210.2007.00729.x

Jegers, M. (2009). Corporate governance in nonprofit organizations. Nonprofit Management and Leadership, 20(2), 143-164. https://doi.org/10.1002/nml.246

Joo, T. W. (2003). A trip through the maze of corporate democracy: Shareholder voice and management composition. St. John's Law Review, 77, 735-774. 
Lupia, A., \& Matsusaka, J. G. (2004). direct democracy: New approaches to old questions. Annual Review of Political Science, 7, 463-482.

Luviene, N., Stitely, A., \& Hyot, L. (2010). Sustainable economic democracy: Worker cooperatives for the $21^{\text {st }}$ century. MITCoLab: Community Innovation Lab, Massachusetts Intitute of Technology, Cambridge.

Moriarty, J. (2016). The demands of stakeholder theory for corporate governance. Business Ethics Journal Review, 4(8), 47-52.

Pestoff, V., \& Hulgard, L. (2015). Participatory governance in social enterprise. Published paper at the $5^{\text {th }}$ EMES International Conference on Social Enterprise. Helsinki, June $30^{\text {th }}$-July $3^{\text {rd }} 2015$.

Putnam, L. L., Fairhurst, G. T., \& Banghart, S. (2016). Contradictions, dialectics and paradoxes in organizations: A constitutive approach. Academy of Management Annals, 10(1), 65-171. https://doi.org/10.1080/1946520.2016.1162421

Rothstein, B. (2001). Social capital in the social democratic welfare state. Politics \& Society, 29(2), 207-241. https://doi.org/10.1177/0032329201029002003

Sauerwald, S., Van Oosterhout, J., \& Van Essen, M. (2016). Expressive shareholder democracy: A multilevel study of shareholder dissent in 15 Western European Countries. Journal of Management Studies, 53(4), 520-551. https://doi.org/10.1111/joms.12171

Solomon, D. (2017). The voice: The minority shareholder's perspective. Nevada Law Journal, $17,739-773$.

Van Puyvelde, S., Caers, R., \& Du Bois, C. (2012). The governance of nonprofit organizations: Integrating agency theory with stakeholder and stewardship theories. Nonprofit and Voluntary Sector Quarterly, 41(3), 431-451. https://doi.org/10.1177/0899764011409757.

Wellens, L., \& Jegers, M. (2014). Effective governance in nonprofit organizations: A literature based multiple stakeholder approach. European Management Journal, 32(2), 223-243. https://doi.org/10.1016/j.emj.2013.01.007.

\section{Copyright Disclaimer}

Copyright for this article is retained by the author(s), with first publication rights granted to the journal.

This is an open-access article distributed under the terms and conditions of the Creative Commons Attribution license (http://creativecommons.org/licenses/by/3.0/). 